\title{
Teaching decolonised New Zealand history in secondary schools
}

\author{
Martyn Davison \\ Pakuranga Collge, Auckland
}

\begin{abstract}
In September 2019, the New Zealand Prime Minister, Jacinda Ardern, announced that it will be compulsory to teach New Zealand history in all of the nation's schools from 2022. To some extent the announcement was a surprise because the New Zealand Curriculum (NZC) is far from being prescriptive and allows teachers autonomy to decide what and how history is covered in the classroom. It was also however, a foreseeable outcome of long-standing and common place assumptions that young people know little or nothing of New Zealand's history (Belich, 2001; Neilson, 2019) and that this can be remedied by making the study of New Zealand history compulsory in schools (Gerritsen, 2019; New Zealand Government, 2019). This article seeks to test these assumptions and in doing so examines the case for teaching New Zealand history, especially from the perspective of a decolonised and inclusive national narrative. It also acknowledges the emergence, within secondary schools, of culturally sensitive and place-based approaches to the teaching of New Zealand history. The article does this by first, describing three recent examples of teaching New Zealand history that adopt these approaches; the last of which, draws upon my classroom practice as a history teacher and teacher-researcher. It then suggests that Te Takanga o te Wãi (Ministry of Education, 2015) ${ }^{1}$ provides a useful framework to further ground these practices in a theory that balances Indigenous and western approaches to teaching history. In the wake of Jacinda Ardern's announcement that New Zealand history will shortly be compulsory in all schools, the article concludes by proposing that a lightly prescribed framework of New Zealand's colonial history in the curriculum will provide history teachers with a more coherent professional landscape.
\end{abstract}

\section{KEYWORDS}

Curriculum, Decolonisation, Indigenous, Māori histories, New Zealand history

\section{Citation}

Davison, M. (2021). Teaching decolonised New Zealand history in secondary schools. Historical Encounters, 8(2), 90-106. https://doi.org/10.52289/hej8.205 


\section{COPYRIGHT}

(C) Copyright retained by Author/s

Published 6 May 2021

Distributed under a CC BY-NC-ND 4.0 License

\section{Introduction}

For those looking in from afar, New Zealand is often described as a young country; the "last large and habitable place in the world to be discovered" (Ministry of Business, Innovation and Employment, 2019, n.p.). Its history spans the settlement of Māori, the indigenous people of Aotearoa New Zealand, whose ancestors arrived from Polynesia around $1200 \mathrm{CE}$, to a present-day diversity, where one in four New Zealanders was born overseas. Any brief history of the country is anchored by events in 1840 when representatives of Queen Victoria and more than 500 Māori tribal leaders signed Te Tiriti o Waitangi / Treaty of Waitangi; one result of which was that New Zealand became a British colony. While the Treaty aspired to bring Māori and the British Crown closer together, different interpretations of what had been agreed and breaches of the Treaty led to conflict. The New Zealand Wars (1843-1872) that followed, witnessed the widespread confiscation or sale of Māori land.

What Te Tiriti o Waitangi had promised Māori regarding land and other resources had not been upheld, the legacy of which continues into the present (Ministry for Culture and Heritage, 2019). Other signposts in New Zealand's history mark periods of: progressive social change (women's suffrage in 1893, and later state pensions and state housing); economic growth (exporting of frozen meat and dairy from 1882); and a developing sense of national identity (independent dominion status in 1907 and a distinctive Anzac (Australian and New Zealand Army Corps) 'spirit' forged in the First World War). More recent history highlights New Zealand's widening role in the Pacific and Asian region and for a variety of reasons its loosening of ties with Britain. As the historian James Belich has theorised however, this separation from Britain has been an uneven process (Belich, 2001). He has characterised the 1860s to the 1880 s as a period of progressive colonisation followed by its collapse and then the later emergence of a re-colonisation that saw New Zealand 'retighten' its relationship with Britain until the 1970s when the forces of decolonisation again took over. Alongside these broad patterns, Belich also highlights one other significant force in New Zealand's recent history, namely "the remarkable twentieth-century resurgence of the Māori people" (Belich, 2001, p. 12). What also seems remarkable is the claim by Belich and other historians such as O'Malley and Kidman (2018), that young people in New Zealand do not learn about this history in secondary school (Husband, 2016).

\section{Young people's knowledge of New Zealand history}

One way of approaching the claim that young people know very little about their nation's history is to ask how much New Zealand history is being taught in secondary schools. The answer seems to be relatively little because history is not a compulsory subject and is only taught as an optional subject in the last three years of schooling; from years eleven to thirteen. This means that only a small proportion of students will study history during their time at secondary school. In 2018, approximately ten percent $t^{2}$ of senior secondary school students were enrolled in history courses (Ministry of Education, 2019). In the same year, a teacher survey $(n=320)$ administered by the New Zealand History Teachers' Association (NZHTA) found that only one in five students opting to take history in Year 11 and 12, will come across New Zealand's nineteenth-century colonial history in their course of study (O'Connor, 2018). While the figure is higher in the final year of schooling, at anywhere between 20 and 50 percent, the survey results show that of the small minority of students who opt to study history, a much smaller number encounter New Zealand's colonial past. 
The correlation between studying a nation's history at secondary school and having a knowledge of that history as a young person however, is not as straightforward as might be first thought. As Wineburg has put it, looking back it seems that almost regardless of what has been taught in the classroom "kids don't know history" (Wineburg, 2001, p. viii). He warns against despairing how little history young people know and instead makes the case for focusing on: what students do know; why they know it; how their personal histories align (or not) with national and world histories; and, how they learn about the past in and out of school. It is important to realise however, that Wineburg's warning emerges from a context where United States history is being taught in secondary school and what he sees as a distraction is the seemingly endless debate of replacing one list of United States history content to teach to students with supposedly a better list of content (Stearns, 1993).

From Rogers (1978) and Shemilt (1980) to Seixas and Morton (2013), history education researchers have argued that history students can be taught to approach the past in much the same way as professional historians do. In this sense, learning the skills of the historian and understanding how they think becomes the priority. It follows, that if historical thinking is being taught in New Zealand secondary schools then there is little to worry about because students can apply this critical way of thinking whenever they encounter New Zealand's history, either in or outside of secondary school. And certainly, in the last decade, publications and conferences that serve the professional community of history teachers in New Zealand, suggest a great deal of local support for a historical thinking pedagogy (Harcourt \& Sheehan, 2012; Davison, Enright \& Sheehan, 2014). Seen narrowly however, as an exclusive pedagogy, there is a danger that teachers assume that historical thinking supplants a need to focus on a quasi-canonical framework of historical content knowledge about New Zealand that secondary students should know. A tendency not to focus on the latter is perhaps more likely because the New Zealand Curriculum (NZC) (Ministry of Education, 2007) makes no attempt to set out what the significant historical events that took place in New Zealand might be.

\section{Why is so little New Zealand history taught in secondary schools?}

The rarity of encountering New Zealand history in secondary schools can potentially be attributed to the country's highly autonomous and non-prescriptive school curriculum. The current NZC document gives history teachers an almost blank canvas to choose to teach what they wish. Should they choose to do so, they are able to largely ignore New Zealand history. This is because within the curriculum's social science learning area, of which history is a part, there is no prescription of any historical content. And, while the NZC's achievement objectives for history does ask teachers to pay attention to events that are of significance to New Zealanders this can be so broadly interpreted that it is almost meaningless in terms of guiding curriculum choices. As a result, history teachers tend to design courses that are a patchwork of topics from conflict in twentiethcentury Europe to the winning of civil rights in the USA (O'Connor, 2018). These topics reflect a pattern of history teachers selecting outwardly facing contexts that are beyond New Zealand's shores (Levstik, 2001). To some extent however, this focus on the non-prescriptive nature of the NZC misses the point that the curriculum documents and indeed the country's Standards for the teaching profession (Teaching Council, 2019) both highlight the importance of Indigenous (Māori) history to New Zealand society.

The NZC clearly acknowledges, within teaching and learning programmes "the principles of the Treaty of Waitangi and the bicultural foundations of Aotearoa New Zealand" (Ministry of Education, 2007, p. 9). The New Zealand standards for the teaching profession elaborate on what this type of aspiration might look like in practice (see Figure 1).

In other words, all New Zealand teachers are being asked to direct their practice towards learning contexts where Indigenous histories, language, identity and culture are affirmed. If, as the NZHTA survey (O'Connor, 2018) suggests, a significant number of history teachers are struggling to achieve this aspiration then there are likely to be a range of reasons. These can be grouped into three categories: an inertia about shifting away from the teaching of largely 
Eurocentric historical content knowledge; a desire to avoid the contentious nature of New Zealand's colonial nineteenth century history; and, a perception that New Zealand history is under-resourced and/or boring.

\begin{tabular}{|l|l|}
\hline STANDARD & ELABORATION OF THE STANDARD \\
\hline $\begin{array}{l}\text { Te Tiriti o Waitangi } \\
\text { partnership }\end{array}$ & $\begin{array}{l}\text { - Understand and recognise the unique status of tangata whenua in } \\
\text { Aotearoa New Zealand. }\end{array}$ \\
$\begin{array}{l}\text { Demonstrate commitment to } \\
\text { tangata whenuatanga and Te } \\
\begin{array}{l}\text { Tiriti o Waitangi partnership in } \\
\text { Aotearoa New Zealand. }\end{array}\end{array}$ & $\begin{array}{l}\text { Understand and acknowledge the histories, heritages, languages and cultures } \\
\text { of partners to Te Tiriti o Waitangi. }\end{array}$ \\
\hline
\end{tabular}

Figure 1: The first of six standards for the teaching profession in New Zealand

(Teaching Council, 2019).

The tendency to teach European history in New Zealand classrooms, especially early-modern British history, is a symptom of neo-colonialism (Belich, 2007). Put simply, this implies that teachers hark back to a sense of Britishness. For many years Tudor and Stuart England has been a popular component of senior history courses in New Zealand secondary schools (Belich, 2007). This inertia however, was not confined only to history teachers. A key opportunity to more widely engage teachers with New Zealand history in the 1990s was also thwarted by the conservatism of the then Department of Education which wished to maintain the status quo of teaching mostly European focused history in secondary schools (Sheehan, 2010). The Department's Forms 5-7 History Syllabus for Schools (Department of Education, 1989) gave European history a dominant position among the topics available to teachers. While it did include topics such as New Zealand history and Māori perspectives it gave little direction as to how they might be taught. Also, it left unchanged the wide range of existing Eurocentric topics taught by history teachers who had been following the 1987 school certificate examination prescription for history, the 1988 sixth form certificate history national course statement, and the 1988 university bursary prescription. Each of these assessment documents favoured content drawn from European history. Furthermore, because the introduction of the 1989 history syllabus was not supported with significant teacher professional development or with any compliance procedures, teachers had little incentive to change what they were doing (Hunter \& Farthing, 2004). Teachers are also influenced by a range of conservative perceptions within their community, from parents and students to colleagues, which also might explain their reluctance to engage with contentious local and national histories (Sheehan, 2017).

New Zealand's colonial history includes many injustices and contentious issues that are perceived as difficult to approach in the history classroom and therefore avoided by some teachers. There is also a sense that history teachers are more comfortable engaging either with largely uncontentious New Zealand history topics such as the 1915 Gallipoli campaign or a contentious past when it is safely drawn from an overseas context. Learning about the contentious parts of New Zealand's history has for some Pākehā (New Zealanders of European descent) upset an ideal image of the country's past which contained "simpler and more rosy conceptions of national identity" (O'Malley \& Kidman, 2018, p. 307). Learning about the injustices of the Jim Crow era America does not test the assumptions of the local community in the same way as exploring the injustices experienced by Māori in the nineteenth century. Trying to understand, however, why teachers might not want to engage with a local and contentious context is quite difficult. After all, in recent times there has been a sustained emphasis in the historical thinking literature on using different concepts such as perspective taking to teach exactly this type of contentious history (Seixas \& Morton, 2013). Drawing upon classroom experiences, history education researcher Michael Harcourt suggests that where students are not practised at historical thinking it is possible to see "a certain desire [for the history teachers] to avoid issues and historical events that students may find difficult, or may not want to learn about at all" (Harcourt, 2015, p. 146). 
Another perception is quite simply that New Zealand history is hard to resource in the secondary school classroom and that students find it boring. This rationalises not teaching New Zealand history by contending that "there were not enough good resources [on New Zealand history] and because students thought it was boring and teachers were afraid of losing enrolments from their senior history classes" (Gerritsen, 2019, n.p.). Regarding resources, a 2018 national survey of teachers ( $n=237$ teacher responses from 165 schools) found that only half of the survey respondents indicated that it was easy to find teacher guides, tools, and exemplars to support teaching about New Zealand (McDowall \& Berg, 2018). It also found that "the problem is not only-or not so much-a lack of resources, but rather a lack of awareness of resources" (McDowall \& Berg, 2018, p. iv); with teacher confidence and familiarity particularly low regarding Māori and local histories. The survey authors concluded that rather than simply produce more resources the solution might be to "design tools to assist teachers and students to create, archive and share their own resources about the histories of their local areas, such as the functionality provided at Digital NZ" (McDowall \& Berg, 2018, p. 35). Allied to the misconception of a lack of resources, is the perception that New Zealand history is boring.

A concern of some teachers is that a course on nineteenth-century New Zealand history would be taught to a half-empty class (Biddle \& Redmond, 2018). Equally, there is a view that students who have encountered New Zealand history in primary or intermediate (middle) school as part of social studies will find it boring to repeat similar content. This point was raised when Year 10 students (aged 14 to 15 years) were interviewed. One student commented that her interest in studying New Zealand and the First World War was "a bit low, probably because ... we have gone through that quite a lot [in primary and intermediate school]" (Davison, 2013, p. 168). History teacher and president of the NZHTA, Graeme Ball, has similarly acknowledged that "sometimes in Year 9 or 10 at our particular school [a large, coeducational, suburban secondary school] when we start to talk about the Treaty [of Waitangi] or something, they'll be 'oh we've done it, we know it'. You dig deeper, they know almost nothing about it" (Gerritsen, 2019, n.p.).

This suggests a lack of coherence when teaching aspects of New Zealand history across primary, intermediate and secondary sectors which potentially contributes to the perception of some students that New Zealand history is boring because they have done it before. While the scope of this article focuses upon the context of secondary school, this is a reminder that what students learn about New Zealand's history before (and indeed after) secondary school is significant.

Until very recently, what was being taught in secondary school history classrooms had generated very little public debate in New Zealand. Usually and perhaps unsurprisingly, it was about what history young New Zealanders did not know. For instance, in 2008, the Sunday Star Times [a New Zealand newspaper] reported about the dismal knowledge of New Zealand's past, among a group of 137, Year Four and Five students (aged nine and ten years). These students had taken part in a New Zealand culture and heritage quiz, and only 14 of them had got more than half the questions right, with most students scoring between 10 and 40 per cent (Scanlon, 2008). However, such articles were relatively rare and did not cause the sort of panic about students' knowledge of historical events that has been seen in the USA (Ravitch \& Finn, 1987) or foster something akin to the so-called history wars in Australia (Macintyre \& Clark, 2004) and the USA (Nash, Crabtree \& Dunn, 1998). In the last five years though, this has dramatically changed.

\section{The call to make New Zealand history compulsory}

In 2015, two secondary school students from Ōtorohanga College ${ }^{3}$, Waimarama Anderson and Leah Bell, spoke publicly about being frustrated with not having the opportunity in school to learn the history of Māori-Pākēha4 ${ }^{4}$ relations, including the New Zealand Wars. By December of that year, having collected over 12,000 signatures, Anderson and Bell had presented a petition to parliament, calling, among other initiatives focusing on commemoration, for this to be addressed by including New Zealand history as a course of study within the country's school curriculum. The argument being put forward was not only about teaching more New Zealand history but teaching those 
aspects of the nation's past connected to injustice and land loss. Appearing on local news media, the students explained why they were seeking change:

Anzac Day ${ }^{5}$ gets taught in schools. But the Land Wars don't. We have done heaps of stuff, over years, I have done poppy-making [commemorating World War One] for example, through all my primary school years, but we have never ever once talked about the Land Wars or the issues in our country over land. (Radio New Zealand, 2014)

Leah Bell's mother, Linda Campbell, who teaches at Ōtorohanga College, felt that young people were being "ripped off from learning their history... ask around [she said] how many of our youth know anything about their own local, let alone national, land and Land Wars history?" (Price, 2016, n.p.).

Inspired by the voices of Waimarama Anderson and Leah Bell, in 2018 the NZHTA, for the first time, took on an advocacy role to promote New Zealand's nineteenth century colonial history in secondary schools. It stated that "an exploration of New Zealand's colonial past is essential as a foundation for understanding what it means to be a bi-cultural citizen" (NZHTA, 2018, n.p.). In its conference of the same year, the NZHTA unanimously passed the resolution that it adopt an activist approach to the teaching of New Zealand's colonial history (NZHTA, 2018). In a subsequent survey, seventy-eight per cent of teacher members agreed with the intent of this resolution. The following year, the NZHTA led a petition to Parliament, asking for New Zealand's colonial history to be included in the school curriculum. It recognised "a zeitgeist moment... [a] time that we took the next step to, in a meaningful way, give young people their history" (NZHTA, 2019, n.p.). Just a few months later, in September 2019, the New Zealand Prime Minister, Jacinda Ardern, announced that New Zealand history would be taught in all schools from 2022. The announcement acknowledged that the coalition Government had listened to the "growing calls from New Zealanders to know more about our own history" (New Zealand Government, 2019, p. 1). The NZHTA warmly welcomed this news (Ball, 2019a) whilst also making it clear that the compulsory teaching of New Zealand history should be accompanied by professional development and sufficient funding of teaching resources to help upskill teachers.

History educator, Tamsin Hanly, has produced her own resources on New Zealand history that she markets directly to schools (Hanly, 2015). Hanly argues that teachers she has interviewed, "either didn't know any or not very much New Zealand history ... [but] these teachers wanted guidance and resources. A lot of teachers felt that they were monocultural around things Māori and therefore they didn't teach it in any context" (Hanly, 2017, p. 5). Because teachers have not been taught New Zealand history themselves, they could not share knowledge of Māori histories. Hanly believes that there has been little change from the time she left school in the 1980s, not knowing anything about Māori histories, to the present. Her argument is that the resources and guidance for teachers is inadequate. As a response she self-published her own teacher guide to New Zealand history and supported it with a professional development programme. The latter is important because it is designed to foster teacher awareness and confidence in teaching New Zealand history; a point also made earlier on by McDowall and Berg (2018). Other organisations have also begun to take far more interest in resourcing the teaching of New Zealand history.

On one level those resources can be found online such as through the Ministry of Culture and Heritage's history website and in the on-line encyclopedia of New Zealand. Both have extensive and relevant information and resources. It presents Māori histories from an iwi [a large group descended from a common ancestor and associated with a specific place] perspective and readers can access material in either English or Te Reo [Māori language]. In print, publishers such as Bridget Williams Books [BWB] have produced numerous books of New Zealand history. A recent example, Tangata whenua: An illustrated history (Anderson, Binney \& Harris, 2014) provides teachers with considerable contextual information [all key BWB texts on New Zealand history are placed, free, in school libraries]. Furthermore, from more specialised educational publishers there are new resources such as the secondary school textbook Expanding World, New Country: 19th Century New Zealand from 3000BCE to today (Ball, 2019b) and New Zealand Wars (Werry, 2018). 
On another level, resources come from the collective memory of Māori and are passed on from one generation to another using waiata [songs to mark important events], whakatauki [proverbs] and pepeha [short sayings]. As the historian Judith Binney has commented, orality has been a way to remember and the stories told face to face have become "markers, guides, comfort and warning" (Binney, 2010, p. 351). While disciplinary history can be highly cautious of oral evidence, Binney's point is that written documentary evidence is also problematic, and often misleading. New digital tools, as McDowall and Berg (2018) argue, offer ways for teachers and students to record and share these oral resources.

\section{The case for teaching decolonised New Zealand history}

If we agree that more New Zealand history, especially its colonial and indigenous history, should be taught, then why so? The Māori Affairs Committee, which reported on Anderson and Bell's petition to parliament, articulated why knowing about one significant aspect of that colonial history, the New Zealand Wars, matters:

The New Zealand Wars covers a period of sustained conflict throughout the country from 1843 to 1872 between Māori on one side, and settlers, the Crown, the New Zealand Government, and Māori on the other side. The New Zealand Wars were primarily a result of disputed land purchases and conflict over sovereignty... In addition to the devastating loss of life, the main consequence of the New Zealand Wars and subsequent legislation was the widespread confiscation of Māori land and resources. The intergenerational impact of these events continues to define the context for Māori-Pākēha relations which in recent times have sought redress through the Waitangi Tribunal and Treaty settlement process ... Much Treaty settlement legislation refers to the detrimental effect of land confiscation on Māori development. (Māori Affairs Committee report, 2017, p. 7)

The argument being made is that to understand this legacy and to consider how it could be redressed it is first necessary to explore its history. The Waitangi Tribunal, since 1985, has done this by investigating Crown breaches of Te Tiriti o Waitangi dating back to 1840. Judith Binney (1940-2011), who like many other New Zealand historians had been involved in providing evidence to the tribunal, pointed out that its detractors tend to criticise its use of historical inquiry "to address, and remedy, present discontents" (Binney, 2010, p. 334). As she argued, this critique, often referred to as presentism, is problematic because it can become "a euphemism for suppressing - yet again - the voices, memories and understandings that had been marginalised in their own times" (Binney, 2010, p. 334). The failure to teach New Zealand's colonial history to the majority of young people in New Zealand is a further example of this suppression. The consequences of such suppression are painfully felt; expressed here by academic and activist, Hana O'Regan, to an audience of teachers:

[O]ur children are often confronted with the effect of our history, but not enlightened as to the cause. The danger of this is that they are left to think - often unconsciously - that the educational challenges and negative stereotypes many of our whänau [extended family, family group] face today - are because they are 'Māori'. (O'Regan, 2018, n.p.)

If we agree that there is a case for teaching decolonised New Zealand history and that, as the NZHTA put it, a zeitgeist moment of change has arrived, it seems logical to support doing something about it. That support however, does not seem to be universal. While the coalition government had cross party backing in parliament for its decision to make New Zealand history compulsory in schools, it is notable that of the 189 written submissions made in select committee to Anderson's and Bell's petition, 138 were strongly opposed (O'Malley \& Kidman, 2018). These submissions "claimed the petition was playing on the guilt of Europeans for the treatment of Māori in the past, fostering racial division and drawing on misleading, selective, 'politically correct' 
views of the past" (Sheehan, 2017, n.p.). When local communities hold these negative beliefs about New Zealand history it can be difficult for students and their teachers to think differently. Levstik (2001) in her study of history students attending four schools in New Zealand, found that when their beliefs about the past differed from the beliefs of the local community, it was difficult for students to empathise historically. She gave the example of Reed [anonymised pseudonym], a student with a Pākehā background, who did not want to understand a Māori perspective. This was because the Māori perspective about the past included the injustices of colonisation and was at odds with his version of history which tended to see racial injustice and land confiscations as something that only happened overseas. The challenge of shifting Reed's belief that "Māori somehow gave the land away" (Levstik, 2001, p. 89) to the colonial settlers, was considerable. It is almost twenty years since Levstik wrote her article however, and arguably such beliefs are now far less likely to be found among young people. As O'Malley and Kidman argue, Anderson and Bell's petition reveals an openness among Māori and Pākehā young people in wanting to learn about New Zealand's colonial history (O'Malley \& Kidman, 2018).

From a different perspective, Ormond and Morgan (2015) highlighted that while it might be desirable to see New Zealand history serving the purposes of the present, that is explaining the impact of colonisation on today's society, they caution that "understanding of the past [does not mean] always looking to trace the origins of today's circumstances" (2015, p. 157). They argue for a less instrumentalist and narrowing approach to history in schools. This is a reminder that the purposes of teaching history at secondary school are manifold and often in tension with one another. In this sense, Wineburg's (2001) point that both the familiar and unfamiliar past are useful ways of engaging students, is helpful. Ironically, it is New Zealand's colonial history that for many students is likely to be the unfamiliar past. Its strangeness "offers the possibility of surprise and amazement, of encountering people, places and times that spur us to reconsider how we conceptualise ourselves as human beings" (Wineburg, 2001, p. 6). The familiar past is perhaps easier, because students know what they will find, but nonetheless important to anchor them in time and place. Again, it is ironic that for many students this familiar past can be found in overseas and seemingly distant contexts. Wineburg's point of course is to avoid the dichotomous thinking of wanting to teach only the familiar or unfamiliar past and instead do both.

\section{Teaching and learning decolonised New Zealand history now: Three examples}

In the last few years, within secondary schools, there has emerged a variety of approaches to the teaching of New Zealand history. What these can look like is briefly described in the following three examples.

First, Ricky Prebble, a history teacher at a Wellington high school, has led a cluster of history teachers in his local area under the Māori History in the School Curriculum project. The cluster's role focuses on making links with local iwi, in this case Te Atti Awa, and working together to create resources that will support the teaching of Māori histories (Prebble, 2015a). Drawing upon the cluster's experiences, Prebble has highlighted the importance of being open to new learning and recognising who are the local experts and guardians 'who can assist in engaging students with Māori history' (Prebble, 2015a, n.p.). He goes on to say that it is the fostering of this relationship, the face-to-face meeting with iwi that is most important. Prebble also acknowledges that this can be difficult because it may not be obvious to a history teacher who they should approach if a school does not have a pre-existing relationship with a local iwi. A model of local clusters of history teachers will likely help to address this issue of individual teachers struggling to make connections.

Second, Michael Harcourt, a history teacher and researcher, also teaching in Wellington, has devised a toolkit of five pedagogical principles, which draw upon the work of Canadian and US teacher educators (Peck, 2010; Epstein, 2009), that can serve as a framework for teaching New Zealand history (see Table 1). 
1. Recognise the identities and interpretive frameworks of students and teachers

2. Actively confront controversial history

3. Connect the past to students' lived realities

4. Recognise and evaluate historical agency

5. Be responsive to place

Table 1: Five principles of culturally responsive history teaching (Harcourt, 2015)

The first principle emphasises valuing students' different accounts of the past and how they intersect with the teacher's views about history. It pays attention to how students and the teacher relate to their own and each other's ethnicities. This aims to encourage sufficient self- awareness for the assumptions that are brought to contentious history to be shared and discussed. In seeking to deliberately teach contentious history, such as New Zealand's colonial past, the second principle acknowledges that without such an intent there is a tendency for teachers to simply ignore this history. As Harcourt points out, not teaching New Zealand's colonial history likely sends a message to students that "Māori history is less significant than other history" (Harcourt, 2015, p. 39). The third and fourth principles draw on the idea that student engagement is strong when students can make connections to historical characters and understand that these characters have (or had) some autonomy to influence their circumstances. The latter helps to challenge often unspoken theories that cast historical characters in two-dimensional terms as powerless victims or exploitative victors. The final principle by asking what happened in the students' local community is closely aligned to a Māori perspective that foregrounds the importance of place. Harcourt also highlights that it is connected to decolonisation because when students look at the history of local places from an Indigenous perspective, they are likely to recognise past injustices and what these might mean for the present and future.

Third, in 2018, I took part in the multi-agency Increasingly Digital Project (Bolstad \& Keane, 2019) which investigated, alongside a small group of teachers, how digital and non-digital resources are used to help teachers and students encounter New Zealand history. It particularly focused on resources from $\mathrm{He}$ Tohu, a permanent exhibition at New Zealand's National Library in Wellington, comprising of three documents: the Declaration of Independence of the United Tribes of New Zealand; Te Tiriti o Waitangi; and, the Women's Suffrage Petition. It also brought together resources commemorating the Endeavour's 1769 arrival in New Zealand, in a temporary exhibition called Tuia Encounters 250. The National Library's website serves as a portal for teachers and students to access relevant resources and learning activities and it has also sent to every secondary school a set of fifteen curiosity cards ${ }^{6}$ to foster student inquiry about New Zealand's history through images of significant objects and accompanying inquiry questions. I have used these resources to develop a unit of work focusing on the intersections of the Māori world, Tupaia [a Tahitian priest] and James Cook in 1769. The focus is on developing an understanding and empathy for each of these three perspectives; and not simply using one as a dominant lens. Students take an inquiry approach, posing historical questions, based on particular artefacts related to the topic, to spark an investigation. I have used the Increasingly Digital Project's curiosity cards with the intention of helping to guide students, through inquiry, to deep historical thinking and exploration. What is perhaps helpful is that by focusing on the way New Zealand intersects with other forces, in this case British and Tahitian, the mistake of what Belich calls a fortress New Zealand attitude is avoided (Belich, 2007). Indeed, it is Belich's argument that a decolonised approach to New Zealand history is one that sees it "intertwined with global history" (Belich, 2007, p. 10). 


\section{Teaching decolonised New Zealand history now and in the future: A framework}

Te Takanga o te Wã is a set of teaching guidelines (Ministry of Education, 2015) that could provide a place-based framework for introducing secondary school students to New Zealand history. Although aimed at younger students, it promotes the universal idea that teachers collaborate with local iwi, hapū (kinship group, sub-tribe) and whanau (family group) to engage students with the stories and histories associated with the school's location. As well as making a connection with place, the framework embraces the idea of look[ing] to the past to inform the present and the future' (Ministry of Education, 2015, p. 2). It does so by drawing upon five themes that are integral to an understanding of Māori histories: whakapapa, tūrangawaewae, mana motuhake, kaitiakitanga and whanaungatanga.

Whakapapa is a concept that acknowledges that young people are part of something with a great longevity. It stretches back to their grandparents and beyond whilst including themselves in the present and extending into the future. Like a timeline, it provides a way of looking at how young people are positioned on a continuum. It is particularly relevant to looking at Māori migration to New Zealand and drawing upon oral histories. The expertise to know what has remained the same and what has changed over time, in the local area, is something that local iwi would help the teacher and students explore.

Türangawaewae is about belonging and identity. It involves seeking to find out what is significant about a local place and asking 'how do I fit in?' A sense of students' tūrangawaewae might be established and/or strengthened by exploring their family histories and getting out into the local environment to find out more about it. A visit to the local marae [a Māori meeting house] provides a way of engaging with the türangawaewae of the local iwi.

Mana motuhake relates to Māori self-determination and the struggle to preserve this during a process of colonialism. It therefore includes the stories of historical loss of land and conflict as well as resistance and protest. It is also the addressing of grievances and settlement. As such it illustrates to students the significant consequences of past actions and what they mean for the present and future.

Kaitiakitanga can be thought of as guardianship of the land and involves students examining local relationships with the land from the earliest settlement. It especially requires students to "compare and contrast the difference in levels of guardianship of the land and the expectations it engendered during the hundreds of years of Māori guardianship and the decades of Pākehā ownership" (Ministry of Education, 2015, p. 11).

Whanaungatanga is the basis of identity and where we come from. It builds from whānau and the idea of nuclear and extended families. And from there, explores other connections to wider groups and how they might act collectively within the local area and beyond. Table 2 displays the themes, questions and prompts highlighted in Te Takanga o te Wa that might emerge when exploring these five concepts in the classroom. They suggest that approaching history using these themes foregrounds identity, place and story as well as the agency of young people and local experts. 


\begin{tabular}{|c|c|c|}
\hline Themes & Questions and prompts & Sample of focusing questions \\
\hline Whakapapa & $\begin{array}{l}\text { Where do I fit in? Who is around } \\
\text { me? }\end{array}$ & $\begin{array}{l}\text { How did early Māori live? } \\
\text { What was Aotearoa New Zealand like when they got } \\
\text { here? }\end{array}$ \\
\hline Tūrangawaewae & $\begin{array}{l}\text { Where is my place? } \\
\text { Where do I fit in? }\end{array}$ & $\begin{array}{l}\text { What stories does the whare whakairo [carved house, } \\
\text { meeting house] tell? } \\
\text { What does the existence of Māori place or road names } \\
\text { and the inclusion of Māori names on monuments or in } \\
\text { cemeteries tell us about our community? }\end{array}$ \\
\hline Mana motuhake & $\begin{array}{l}\text { Each local area has its own story } \\
\text { Holding on to mana motuhake }\end{array}$ & (none provided for this theme) \\
\hline Kaitiakitanga & $\begin{array}{l}\text { Conflicting values } \\
\text { Restoration and rāhui [temporary } \\
\text { ban / conservation measure] } \\
\text { What is around me? } \\
\text { Taonga [a treasure / a prized } \\
\text { object] is history }\end{array}$ & $\begin{array}{l}\text { In the context of a taonga why is this artefact special? } \\
\text { What does it tell us about you? }\end{array}$ \\
\hline Whanaungatanga & $\begin{array}{l}\text { Who do we come from? } \\
\text { Passing on and sustaining culture } \\
\text { Change makers } \\
\text { A show of unity } \\
\text { Children are an important part of } \\
\text { the history of Aotearoa New } \\
\text { Zealand }\end{array}$ & $\begin{array}{l}\text { How were family and tribal relationships changed by } \\
\text { conflict, intermarriage, and forced or unforced } \\
\text { migration? } \\
\text { How were communities changed as their leaders were } \\
\text { killed, imprisoned, or undermined? }\end{array}$ \\
\hline
\end{tabular}

Table 2: Themes from Te Takanga o te Wā

(Ministry of Education, 2015, pp. 5-15)

\section{Conclusion}

The view that many young people know little or nothing of New Zealand's history is reasonably justified. There are many reasons why this might be the case, including: too few students following a pathway in secondary school that includes the subject of history; and, until very recently a high autonomy curriculum that meant teachers could avoid, if they wished, the contentious nature of New Zealand's colonial history. The assertion however, that they include the idea that New Zealand history is boring and poorly resourced is unwarranted. Newly published resources, from Graeme Ball's secondary school textbook Expanding world, new country (Ball, 2019b) to digitally curated artefacts at the National Library of New Zealand, illustrate the engaging nature of New Zealand history and a commitment to making the country's past accessible to teachers and students.

Until a very short time ago, it might have been said that simply acknowledging that New Zealand history is rarely taught in secondary schools will do little however, to change the status quo. More than thirty years ago the prominent New Zealand historian, Keith Sinclair, lamented that "[history] has nearly no place in our school timetables" (Sinclair, 1986, p.1). That a generation of new historians have said much the same thing in this decade, suggested that the status quo had been remarkably durable (O'Malley \& Kidman, 2018). Then, in September 2019, the Prime Minister's announcement that New Zealand history will be taught in all schools from 2022, rather dramatically changed things.

As history teachers begin to ask what will happen in the lead up to 2022, there are already promising signs about what the teaching of New Zealand history in schools might look like. Te Takanga o te Wã (Ministry of Education, 2015) provides teachers with a framework regarding how New Zealand history could be taught in ways that embrace both historical thinking as 
described by Seixas and Morton (2013) and a culturally sensitive theory of place-based histories. As this article has highlighted, there are examples of this approach being used in the classroom to deliberately engage with the contentious nature of New Zealand's colonial history (Prebble, 2015b; Harcourt, 2015). Alongside this practice will soon sit an agreed national framework of content knowledge about New Zealand history within the NZC document. At this stage, the coalition government has signalled that this will likely include the following:

The Arrival of Māori to Aotearoa New Zealand

First encounters and early colonial history of Aotearoa New Zealand

Te Tiriti o Waitangi / Treaty of Waitangi and its history

Colonisation of, and immigration to, Aotearoa New Zealand, including the New Zealand Wars

Evolving national identity of Aotearoa New Zealand in the late nineteenth and early twentieth centuries

Aotearoa New Zealand's role in the Pacific

Aotearoa New Zealand in the late twentieth-century and evolution of a national identity with cultural plurality

Table 3: Framework of content knowledge about Aotearoa New Zealand history

(New Zealand Government, 2019, p. 1)

Another way of thinking about content is as a series of elements, as outlined in James Belich's Dominion Day symposium address (Belich, 2007). Accordingly, the framework would include New Zealand's nineteenth century colonial history with an emphasis on its "trans-national, transdisciplinary, trans-cultural, innovative, and dramatic [elements]" (Belich, 2007, p. 10). To take just one of these elements, the trans-cultural, there is an opportunity to teach the migrations and interactions of Māori, Pākehā, Pacific Islanders and the Chinese. Exploring the histories of how these global cultures come together locally in New Zealand is what Belich calls a civic nationalism or more descriptively "a point of mediation between the global and the local" $(2007$, p. 10). The expectation is that studying New Zealand history could help secondary school students develop a highly inclusive idea of what it is to be a New Zealander. Prescribing New Zealand historical content, to serve a moral purpose that might be called civic nationalism or more simply understanding how the past has shaped New Zealand's present, is not without controversy.

The process of prescribing content produces a healthy scepticism among history teachers who are suspicious of centralised attempts to control what is taught (Enright, 2016). Yet, done well, prescribing at least some of what is taught in history classrooms can avoid the politically motivated and narrow version of history that is of concern here. Drawing upon the experiences of teachers in England and Wales, Husbands, Kitson and Pendry (2003, p. 139) have noted that a history curriculum with a relatively light prescription can quickly become part of the professional landscape and not only "a resource to be deployed in supporting pupil learning," but a means for greater coherence.

It is apt to conclude with the voice of one of those most closely associated with advocating for this new landscape that includes the compulsory teaching of New Zealand's colonial history. Responding to the announcement that New Zealand history will be taught in all schools from 2022, Leah Bell, a student from Ōtorohanga College and co-sponsor of the 2015 petition to parliament calling for just such an action, said that "this is such an exciting prospect for all of us here in Aotearoa [New Zealand] to explore our history, to garner a greater sense of unity and understanding of who we are" (cited in McCarthy, 2019, n.p.). 


\section{References}

Anderson, A., Binney, J., \& Harris, A. (2014). Tangata whenua: An illustrated history. Wellington, New Zealand: Bridget Williams Books.

Ball, G. (2019a, September 17). NZHTA (New Zealand History Teachers' Association) letter to PM Ardern. Retrieved from https://nzhta.org.nz/news/nzhta-letter-to-pm-adern

Ball, G. (2019b). Expanding world, new country: 19th Century New Zealand from 3000BCE to today. Sydney, Australia: Cengage Learning.

Barton, K. C., \& Levstik, L. S. (2004). Teaching history for the common good. Mahwah, NJ: Lawrence Erlbaum Associates.

Belich, J. (2001). Paradise reforged: A history of the New Zealanders from the 1880s to the year 2000. Auckland, New Zealand: Penguin Press.

Belich, J. (2007). Globalization and the nation. Keynote address to the concepts of the nation symposium. Retrieved from https://nzhistory.govt.nz/files/documents/JamesBelichGlobalizationandNation.pdf

Biddle, D. L., \& Redmond, A. (2018, September 13). History teacher: Students say NZ Wars 'too boring'. Retrieved from https://www.stuff.co.nz/national/education/107046200/historyteachers-lament---students-say-nz-wars-too-boring

Binney, J. (2010). History and memory. In J. Binney, Essays 1975-2010 - Stories without end. (pp. 332-352). Wellington, New Zealand: Bridget Williams Books.

Bolstad, R., \& Keane, B. (2019). Increasingly digital project. Wellington, New Zealand: Department of Internal Affairs and New Zealand Council for Educational Research.

Davison, M. (2013). 'It is really hard being in their shoes': Developing historical empathy in secondary school students. (Doctor of Education dissertation, The University of Auckland).

Davison, M., \& Enright, P., \& Sheehan, M. (Eds.). (2014). History matters 2: A handbook for teaching and learning how to think historically. Wellington, New Zealand: NZCER Press.

Enright, P. (2016, December 30). Reply to Mark Sheehan, "A historically conscious future" Indigenous perspectives on war remembrance, Public History Weekly, 4 (2016) 15. Retrieved from https://public-history-weekly.degruyter.com/4-201615/indigenous_war_remembrance_new_zealand/

Epstein, T. (2009). Interpreting national history: Race, identity, and pedagogy in classrooms and communities. New York, NY: Routledge.

Gerritsen, J. (2019, February 5). Shameful ignorance of colonial, Maori history. Retrieved from https://www.radionz.co.nz/news/te-manu-korihi/381749/history-teachers-decryshameful-ignorance-of-colonial-maori-history

Hanly, T. (2015). A critical guide to Māori and Pākehā histories of Aotearoa: a curriculum programme for educators. Auckland, New Zealand: Tamsin Hanly.

Hanly, T. (2017). An interview with Tamsin Hanly. History Teacher Aotearoa, 1(4), pp. 4-6. 
Harcourt, M. (2012). Where to next? Some final thoughts on the future of history teaching in New Zealand. In M. Harcourt \& M. Sheehan (Eds.), History matters: Teaching and learning history in New Zealand secondary schools in the 21st century. (pp. 141-148). Wellington, New Zealand: NZCER Press.

Harcourt, M. (2015). Towards a culturally responsive and place-conscious theory of history teaching. SET Research Information for Teachers, 2, 36-44.

Harcourt, M., Milligan A., \& Wood B. (Eds.). (2016). Teaching Social Studies for critical, active citizenship in Aotearoa New Zealand. NZCER Press, Wellington, New Zealand.

Hunter, P., \& Farthing, B. (2004). Talking history - teachers' perceptions of 'their' curriculum in the context of history in the New Zealand curriculum, 1980-2003. Hamilton, New Zealand: Wilf Malcolm Institute for Educational Research, University of Waikato.

Husband, D. (2016, October 15). Vincent O'Malley: Too many Pākehā don't know our history. Retrieved from https://e-tangata.co.nz/korero/too-many-pakeha-dont- know-our-history/

Husbands, C., Kitson, A., \& Pendry, A. (2003). Understanding history teaching. Maidenhead, England: Open University Press.

Keenan, D. (2012). Huia Histories of New Zealand: Ngā Tāhuhu Kōrero. Wellington, New Zealand: Huia Publishing.

Levstik, L. S. (2001). Crossing the empty spaces: Perspectives taking in New Zealand adolescents' understanding of national history. Lanham, MD: Rowman and Littlefield.

Manatū Taonga Ministry for Culture and Heritage. (2019). Story: Treaty of Waitangi. Retrieved from https://teara.govt.nz/en/treaty-of-waitangi/page-4

Māori Affairs Committee report. (2014). Petition 2014/37 of Waimarama Anderson and Leah Bell. Retrieved from https://www.parliament.nz/resource/enNZ/51DBSCH_SCR72212_1/11afd2f0d20ef35b78e55ffa95d252f6aed69026

Māori Television. (2015, December 7). Students prepare to take New Zealand Land Wars petition to Parliament. Retrieved from https://www.maoritelevision.com/news/regional/studentsprepare-take-nz-land-wars-petition-parliament

McCarthy, A. (2019, September 17). Looking back at calls for New Zealand history in schools. Retrieved from https://www.rnz.co.nz/national/programmes/thehouse/audio/2018713466/looking-back-at-calls-for-new-zealand-history-in-school

McDowall, S., \& Berg, M. (2018). Increasingly digital Project teaching and learning resources in the context of Aotearoa New Zealand: A national survey of schools for the Increasingly Digital project. Retrieved from https://natlib.govt.nz/schools/our-work/increasingly-digital-project

Mcintyre, S., \& Clark, A. (2004). The history wars. Melbourne, Australia: Melbourne University Press.

Ministry of Business, Innovation and Employment. (2019). A brief history. New Zealand Now. Retrieved from https://www.newzealandnow.govt.nz/living-in-nz/history-government/abrief-history

Ministry of Education. (2015). Te Takanga o te Wā Maori history: Guidelines for Years 1-8. Retrieved from http://maorihistory.tki.org.nz/assets/Uploads/Te-Takanga-o-te-Wa-MaoriHistory-Guidelines-English-1.pdf 
Ministry of Education. (2017). Māori history in the New Zealand curriculum. Retrieved from http://maorihistory.tki.org.nz/en

Nash, G. B., Crabtree, C., \& Dunn, R. E. (1998). History on trial: Culture wars and the teaching of the past. New York, NY: Alfred A. Knopf.

Neilson, M. (2019, May 18). The New Zealand Wars: Historian Vincent O’Malley says we need to confront 'our bloody history'. New Zealand Herald. Retrieved from https://www.nzherald.co.nz/nz/news/article.cfm?c_id=1\&objectid=12231431

New Zealand Government. (2019, September 12). NZ history to be taught in all schools. Retrieved from https://www.beehive.govt.nz/release/nz-history-be-taught-all-schools

New Zealand History Teachers' Association. (2018). New Zealand History Teachers' Association submission to the NCEA Review. Retrieved from https://nzhta.org.nz/resources/historypromotion/history-promotion-letters

New Zealand History Teachers' Association. (2019). [Media statement]. "Give me my history" NZHTA petition. Retrieved from https://nzhta.org.nz/news/give-me-my-history-nzhtapetition

O'Connor, P. (2018). Common themes from the New Zealand History Teachers' Association survey on the teaching of New Zealand's colonial history. New Zealand History Teachers Association (NZHTA). Retrieved from https://nzhta.org.nz/resources/history-promotion/historypromotion-letters

O'Malley. V. (2016). The great war for New Zealand: Waikato 1800-2000. Wellington, New Zealand: Bridget Williams Books.

O'Malley, V., \& Kidman, J. (2018). Settler colonial history, commemoration and white backlash: Remembering the New Zealand Wars, Settler Colonial Studies, 8(3), 298-313. https://doi.org/10.1080/2201473X.2017.1279831

O’Regan, H. (2018). To reo ki te raki, tō mana ki te whenua. Keynote address at the ULearn Conference, Core Education Ltd, Auckland, New Zealand.

Ormond, B., \& Morgan, J. (2015). A history curriculum for New Zealand in the 21st century. In J. Morgan (Ed.), The 21st Century Curriculum? (pp.152-161). Auckland, New Zealand: Edify Ltd.

Peck, C. L. (2010). 'It's not like [I'm] Chinese and Canadian. I am in between': Ethnicity and students' conceptions of historical significance. Theory and Research in Social Education, $38(4), 574-617$.

Price, R. (2016, March 30). Ministry of Education refuses to include New Zealand Land Wars in curriculum. Retrieved from https://www.stuff.co.nz/national/politics/78386446/ministryof-education-refuse-to-include-new-zealand-land-wars-in-curriculum

Prebble, R. (2015a, February 9). At the heart of the school. Education Gazette 94, 2. Retrieved https://gazette.education.govt.nz/articles/1H9cqG-at-the-heart-of-the-school

Prebble, R. (2015b). Teaching Māori history in today's world. Te kete ipurangi Māori history in the NZ curriculum. Retrieved from http://maorihistory.tki.org.nz/en/contexts/iwi-and-localhistory/video-stories 
Radio New Zealand, (2014, August 24). Conflict history: Leah Bell and Waimarama Anderson. Retrieved from https://www.radionz.co.nz/national/programmes/sunday/audio/20146885/conflicthistory-leah-bell-and-waimarama-anderson

Rogers, P. (1978). The new history: Theory into practice. London: The Historical Association.

Scanlon, S. (2008, May 11). Primary schoolchildren struggle with general knowledge. Sunday Star Times. Retrieved from http://www.stuff.co.nz/sundaystartimes /4520911a6442.html

Seixas, P., \& Morton, T. (2013). The big six historical thinking concepts. Toronto, ON: Nelson Education.

Sharples, P. (2012). Opening speech to the New Zealand History Teachers' Association Conference, Wellington, 4 October 2010. In M. Harcourt \& M. Sheehan (Eds.), History matters: Teaching and learning history in New Zealand secondary schools in the 21st century (pp. 149153). Wellington, New Zealand: NZCER Press.

Sheehan, M. (2010). The place of 'New Zealand' in the New Zealand history curriculum. Journal of Curriculum Studies, 42(5), 671-691. https://doi.org/10.1080/00220272.2010.485247

Sheehan, M. (2016, April 28). A historically conscious future - Indigenous perspectives on war remembrance. Public History Weekly, 4 (2016) 15. http://dx.doi.org/10.1515/phw-20165998

Sheehan, M. (2017, January 19). A matter of choice - biculturalism. Public History Weekly, 5 (2017) 2. http://dx.doi.org/10.1515/phw-2017-8094

Shemilt, D. (1980). History 13-16: Evaluation study. Edinburgh: Holmes McDougall.

Sinclair, K. (1986, November 24). Letter to the New Zealand Listener. Wellington, New Zealand: New Zealand Broadcasting Corporation.

Snedden, P. (2005). Pākehā and the Treaty: Why it's our treaty too. Auckland, New Zealand: Random House.

Stearns, P. N. (1993). Meaning over memory: Recasting the teaching of culture and history. Chapel Hill, NC: The University of North Carolina Press.

Teaching Council. (2019). Our code, our standards. Wellington, New Zealand: Teaching Council of Aotearoa New Zealand. Retrieved from https://teachingcouncil.nz/content/our-code-ourstandards

Werry, P. (2018). The New Zealand Wars. Wellington, New Zealand: New Holland Publishers.

Wineburg, S. (2001). Historical thinking and other unnatural acts: Charting the future of teaching the past. Philadelphia, PA: Temple University Press. 


\section{Endnotes}

${ }^{1}$ Te Takanga o te $W a \bar{a}$ is a set of guidelines for teaching Māori history, published by the Ministry of Education. It is aimed at teachers in Year 1 to 8 classrooms (primary and middle schools) but is also relevant to secondary school settings.

${ }^{2}$ In 2018, 329,051 students were enrolled in New Zealand's National Certificate of Educational Achievement (NCEA); the country's public qualification for senior high school students. Of those, 31,016 were enrolled in NCEA History.

${ }^{3}$ Ōtorohanga College is a rural secondary school in the Waikato district of New Zealand's North Island.

${ }^{4}$ Pākēha refers to New Zealanders of European descent.

5 “Anzac Day occurs on 25th April. It commemorates all New Zealanders killed in war and also honours returned servicemen and women. The date itself marks the anniversary of the landing of New Zealand and Australian soldiers - the Anzacs - on the Gallipoli Peninsula in 1915.” Retrieved 8 November, 2019, from https://nzhistory.govt.nz/war/anzac-day/introduction.

${ }^{6}$ The National Library's curiosity cards can be accessed online: https://natlib.govt.nz/schools/teaching-and- learningresources/teaching-tools-resource-guides/curiosity-cards-for-inquiry.

\section{Acknowledgements}

The author would like to thank Robert Guyver, Peter Brett and the historian Vincent O'Malley for their valuable comments and advice.

\section{About the Author}

Martyn Davison is a history teacher. He began teaching in south west England in 1996 and took the plunge to New Zealand's Pacific shores in 2002. He encourages students to think critically and empathically about the past. Martyn's doctoral research explored the role of empathy in the history classroom. He is currently collaborating with the history community to implement curriculum changes that will see New Zealand history being taught in all schools by 2022. Martyn believes that teachers are strongest when they generate, as well as consume, educational change. The author can be contacted at the email address below.

Email: DAV@pakuranga.school.nz 